\title{
Intended for the stage: Performance criticism in Richard Brome's The Antipodes
}

\author{
Miguel Ramalhete Gomes \\ Universidade do Porto
}

\begin{abstract}
This note focuses on the troubled relation between Richard Brome's The Antipodes (1638) and its theatrical realisations, as mentioned in the author's address to the reader in the Quarto of 1640 as well as has been the case in more recent revivals of the play. Criticism of early modern drama has tended to consider such plays as determined by their being written for performance, an emphasis which has sometimes entailed a dismissal of more textual approaches. However, in The Antipodes there seems to have existed (and continues to exist) some disconnectedness between the text of the play and its life in the theatre. I therefore propose looking at specific aspects of The Antipodes in relation to the challenges it poses in performance and to performance criticism, by continuously shifting between the Caroline theatrical context and the contemporary critical and theatrical context.
\end{abstract}

KEYWORDS: Richard Brome; Caroline drama; performance; reading; play-within-the-play; paratext; adaptation.

That early modern drama should be understood primarily in relation to its theatrical performance is nowadays a critical truth. We can find it, for instance, in the introductory texts in The Norton

\footnotetext{
* This study was carried out in the framework of project PEst-OE/ELT/UI4097/2011, hosted by CETAPS (Centre for English, Translation and Anglo-Portuguese Studies) and funded by FCT - Fundação para a Ciência e a Tecnologia, Portugal. It is also part of an ongoing post-doctoral research project (SFRH/BPD/75848/2011), funded by FCT, and dealing with contemporary forms of presentism.
}

$$
\text { (C) ederi 24 (2014: 157-169) }
$$

https://doi.org/10.34136/sederi.2014.8 
Shakespeare, qualified on the cover as an "International Student Edition." These texts could be said to represent the consolidated positions that, at least as late as 2008, the year of the second edition, were understood to be worth transmitting to students as introductory information regarding Shakespeare, the theatre of his time and their historical context. In the first of these texts, Stephen Greenblatt discusses the relation between theatrical script, stage performance and printed play, and concludes that "These developments [...] highlight elements that Shakespeare shared with his contemporaries, and they insistently remind us that we are encountering scripts written primarily for the stage and not for the study" (2008:71). On the opening page of the second introductory text, the well-known essay "The Shakespearean Stage," Andrew Gurr insists on the same point: "Shakespeare's own primary concept of his plays was as stories 'personated' onstage, not as words on a page" (2008:79). As we know, the history of this position is already some decades old, having originated as a healthy and necessary corrective to the exclusively textual focus of approaches such as those stemming from New Criticism. Performance criticism is now an established part of early modern drama studies, be it on the side of a historical contextualisation of early modern drama or on the side of the afterlives of these plays. On the one hand, we now know considerably more about these plays' original conditions of production; on the other hand, a history of the performance of these plays has become a solid part of the study of their afterlives, since performance is also an instance of production of meaning.

However, throughout the past decade, some have worried that this view may have become too prevalent or too dogmatic. Lukas Erne, probably the most outspoken critic of the aforementioned position, has argued that "For many adherents of the now omnipresent performance criticism, the basic premise underlying their approach to Shakespeare is the claim that his plays were written in order to be performed" (2003:14, my italics). In an attempt to propose a corrective to the corrective of performance criticism, Erne has maintained that, "from the very beginning, the English Renaissance plays we study had a double existence, one on stage and one on the printed page" (2003:23). In fact, Erne inverts the usual topos regarding the relation between theatre and print by making the case that "In a sense, what is particular about the time of Shakespeare's active involvement with the theater in London is that 
plays stopped having a public existence that was confined to the stage" (2003:14). Rui Carvalho Homem has also stressed the importance of a textual and bibliographical approach capable of complementing a theatrical one:

There is the need [...] to mitigate the argument which derives from the unquestioned realisation that Shakespeare's dramatic texts were written for performance, the precept that reading them as anything other than playscripts is a fundamental misunderstanding. Against this, the argument (re)emerges that a historically alert reading will have to include the ballast of meanings and the cultural consequence which accrued with the long tradition of reading Shakespeare's plays as literature, on the page (2004:9).

Furthermore, attention has been called to the analogy between theatrical and textual performance in editions of early modern texts, since, according to W. B. Worthen, both "materialize the work as a unique event in time and space," so that each "Hamlet on the stage uses Shakespeare's words, and much else, to fashion a new and distinctive performance; each Hamlet on your shelf uses Shakespeare's words, and much else, to fashion a new and distinctive performance" (2005:10).

Although the above remarks apply to Shakespeare, they have also been used in regard to many of his contemporaries, even if sometimes in a less emphatic manner. There are, of course, several known exceptions to the general attitude derived from the example of Shakespeare's apparent disinterest in published drama. There is the case of Ben Jonson and his 1616 Folio, which included heavily revised versions of Jonson's plays, namely of those written in collaboration. Jonson, as we know, was ridiculed for the presumption of publishing such a tome during his lifetime, and this reaction tells us much about current attitudes towards the literary value of drama. As far as authorial assertiveness goes, Shakespeare's example, or at least his example according to us, can be said to be slowly waning as we reach Jacobean and especially Caroline times. Nevertheless, despite this historical change, Greenblatt's and Gurr's comments can still be said to echo a general contemporary tendency to privilege the analysis of most drama, not just early modern drama, in connection with the theatre and only secondarily as a textual object. 
It is in the context of this debate that I would like to discuss the implications of a very small text, only a few lines long, not by Shakespeare, but by Richard Brome. Initially known as Ben Jonson's manservant and later as a successful playwright in his own name, Brome absorbed some of Jonson's authorial consciousness and pride. One of the fascinating aspects of Brome's The Antipodes (first staged in 1638, published in quarto in 1640) has been its relation to the theatre, in terms of its meta-theatrical dimension but especially in terms of the play's theatrical realisation, as it is referred to in the author's address to the reader and as is implicit in the text. In fact, in The Antipodes there seems to have existed, and to continue to exist, some disconnectedness between the text of the play and its theatrical realisation. Even though the play was indeed written for the stage, it seems that the stage has had some difficulty in dealing with a text apparently tailored for it.

In a note addressed to the reader, printed in the 1640 quarto of the play, Brome explains his authorial resentment at certain playhouse practices:

Courteous Reader:

You shall find in this book more than was presented upon the stage, and left out of the presentation for superfluous length (as some of the players pretended). I thought good all should be inserted according to the allowed original, and as it was at first intended for the Cockpit stage, in the right of my most deserving friend, Mr. William Beeston, unto whom it properly appertained. And so I leave it to thy perusal as it was generally applauded, and well acted, at Salisbury Court.

Farewell, Richard Brome. (2000:120)

The troubled history of this play and of Brome's problems with Salisbury Court theatre is well documented and helps to explain this somewhat tense, though restrained address. ${ }^{1}$ We know that Brome

\footnotetext{
${ }^{1}$ Brome's statement regarding the restoration for publication of passages cut for performance is common enough in the period, as Andrew Gurr (1999:80), Lukas Erne (2003:144-145), and David Scott Kastan (2001:16-20) point out. In the 1623 Quarto of The Duchess of Malfi, for instance, one can read the following paratext: "The perfect and exact copy, with diverse things printed that the length of the play would not bear in the presentment" (Webster 2009:116). One of the distinguishing marks of Brome's text is the expression of irritation towards the players apparent in his note. As Richard Cave has pointed out, Brome's note "suggests he had a proprietorial interest in the publication as presenting his full composition, which he takes care to separate from
} 
signed an exclusivity contract with Salisbury Court theatre in $\mathbf{1 6 3 5}$. A later contract, from 1638, included a clause prohibiting any publication of the plays without the theatre's consent, and Matthew Steggle (2004:68) argues that the first contract may have included an

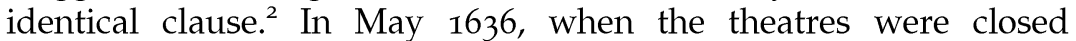
because of the plague, Salisbury Court suspended its weekly payments to Brome, and, Brome later said in a deposition, threatened to cancel the contract altogether. Brome apparently felt he was free to seek work elsewhere. He then agreed with William Beeston to write a play for his Cockpit Theatre, a play which, it is generally agreed, was The Antipodes. Salisbury Court, probably fearing the loss of its investment, took possession of the play, paid Brome and promised to release him from his obligations to Beeston. When the theatres reopened, the play was staged with great success. But tensions at Salisbury Court and increasing friction with Brome, including a legal claim, produced further complications which ended with Brome finally leaving Salisbury Court for the Cockpit in August 1640. Before that, on 19 March, he entered The Antipodes as well as two other plays in the Stationer's Register and both The Antipodes and The Sparagus Garden were published later that year. ${ }^{3}$

Some of Brome's problems with Salisbury Court had to do with the degree of input allowed to the players, who allegedly made cuts because the play was superfluously long. Brome's observation, "(as some of the players pretended)," shows his disgruntlement, while the publication is meant to vindicate his position by presenting the play to the public in its original form, not the one tampered with by the players. The reference in Brome's note to "the allowed original" further reveals that the authorial version was the one that was

the version played by the actors" (2010:n.p.). The following account of Brome's troubles with Salisbury Court closely follows and summarises the exposition in Steggle (2004:105-109; 118-120).

${ }^{2}$ For more on this contract, see Collins (2010).

${ }^{3}$ In August 1640, Brome entered a further six plays in the Stationers' Register. Matthew Steggle (2004:156-157) convincingly argues that Brome may have been trying to raise some money through print publication, after the performance at the Cockpit of an unnamed play, normally thought to be Brome's The Court Beggar, was prohibited by the Master of the Revels in early May, on account of certain passages on the Scottish Wars. This prohibition was aggravated by the arrest of Beeston and two players, as well as by the appointment of William Davenant as manager of the company, in late June. 
approved by the Master of the Revels. ${ }^{4}$ The reason for the players' dislike of parts of the play, Brome suggests, has to do with the characteristics of that specific troupe. According to Brome, the play had been written with the specificities of the Cockpit in mind; it had been intended and tailored for it. No wonder then that the players of Salisbury Court may have been little at ease with it. Of course, we do not know what the players of the Cockpit thought of this play written for them, whether they would have felt the play suited them impeccably. Would we perhaps be justified in seeing this as an excuse with which Brome could rationalise actual shortcomings of the play, and would the players from the Cockpit also have cut it if they had had the chance?

With these questions and the theatrical context in mind, I would now like to turn to the year 2000, the time of the first revival of The Antipodes since the mid-eighteenth century. In 2000, the New Globe Theatre staged the play in an adaptation by Gerald Freeman. According to Matthew Steggle (2004:195), the play was cut by about a third. The uncut play was then published in the Globe Quartos collection, with an interesting note by the adapter. Freeman argues that "There is no getting away from the fact that nowadays there are parts of The Antipodes which may work on the printed page, but do not on the stage" (2000:vii). Freeman explains that he cut those moments of the play which depended too much on the recognition of certain seventeenth-century types which had not really been theatricalised, such as the onstage audience's comments related to the satire in the play-within-the-play. Drawing on the original precedent, Freeman adds that "One gains some confidence and comfort in cutting and pruning from a printed apology (or disclaimer) of the author [...]. The players apparently discovered something in the playing that had escaped the author."

\footnotetext{
4 See Gurr (1999:70) and Kastan (2001:20). One may ask whether the play was "allowed" by the Master of the Revels while it was still meant for the Cockpit, as Brome seems to suggest when he brings together these two qualifiers: "according to the allowed original, and as it was at first intended for the Cockpit stage." One is thereby left to wonder whether the Master of the Revels might have facilitated Brome's turn to a different company. Nevertheless, Brome's contradictory remark at the end of the note, to the effect that he leaves the play to the readers' "perusal as it was generally applauded, and well acted, at Salisbury Court," only confuses matters again, implying that Brome is trying to have it both ways, by capitalising on the authorial value of the original text as well as on the success of its stage version.
} 
It should perhaps be added that, in 1992, when the Royal Shakespeare Company revived another play by Brome, A Jovial Crew, it also adapted it. The adaptation by Stephen Jeffreys included about forty-five per cent of new text and Jeffreys argued that, as it stood, the play seemed unperformable, not only because of topical references that had lost their comic point, but also because of insuperable problems in terms of its structure. ${ }^{5}$ According to his own note, Jeffreys' aim was "to make Brome's comic conception work on stage" (1992:n.p.), a well-known phrasing that Freeman also echoes. Julie Sanders, on the other hand, has seen this need to adapt Brome as proof of "the poor regard in which Caroline drama is held" (1999:8). ${ }^{6}$

Nevertheless, stage adaptations are an extremely common affair. Even Shakespeare's plays are usually cut for performance. In this context, one would do well to point to the prolific and often startlingly original field of textual, filmic, and operatic adaptations, among other types. Unlike what might appear to be the case so far, my position here is definitely not that of the textual purist berating others for taking theatrical or other liberties. What interests me here is how these two paratexts, Brome's apology and Freeman's note (as well as Jeffreys' note, although it refers to a different play), seem to complicate what it means to look at a play as a text written for the stage. Freeman not only begins by arguing that, as it stands, this play may work better on the page than on the stage, but adds a further twist to his use of Brome's apology. It is no longer an issue of the play being better suited for one company rather than another. It now appears that the play is simply found deficient in terms of its theatrical effectiveness. It just does not work on the stage, any stage.

A perspective such as this one, though not uncommon in the theatre world, really only becomes academically tenable today, in a time when, in the wake of performance criticism, we now

\footnotetext{
${ }^{5}$ Jeffreys argues that "the central dramatic problem is resolved too quickly and so the second half falls apart [...]; the denouement is wildly implausible and contradicts much of the psychology of the central character" (1992:n.p.). Paradoxically, Jeffreys' concern for outdated comic references is contradicted by his insertion of "fake' topical references" (Steggle 2004:194) and "'mock-antique' details" (Stern 2014:61). Rather than pruning early modern references, Jeffreys actually added more "historical" material.

${ }^{6}$ For an analysis of Jeffreys' adaptation, see White (1998:217-232).
} 
understand early modern playwrights to have been mere employees of a company, their input as important as that of the players, in what was essentially a collective enterprise. It also replaces a theatrical absolute for what, until recently, had been a literary absolute. A play is considered structurally deficient simply because, according to the banal phrase, it does not work on the stage. This is already a limited view of theatre practices, since what is meant here by this suspiciously universal expression, "the stage," is the standard type of staging which is currently applied to early modern plays, especially when one considers such canonical venues as the New Globe Theatre or companies such as the Royal Shakespeare Company. Furthermore, the condemnation according to which a play is summarily said not to work on "the stage" erases, through its generalisation, what is arguably one of the most distinctive traits of the theatre: its capacity to produce unique events and specific readings of a text, in that the adoption of one performative solution always implies the rejection of several other possibilities, many of which may be equally valid or even perhaps more appropriate to the text at hand. Finally, the idea of rejecting a text because of its inadequacy according to a chosen set of theatrical conventions becomes extremely problematic once we begin using it to pronounce aesthetic judgments on a dramatic text.

Taking the play fully seriously - the printed play, not the players' version of it, which is not extant and about which one can only speculate ${ }^{7}$ - might mean to stage it with all its inadequacies; that is, with those parts of it which appear not to "work on the stage." Indeed, as we know well from the history of the theatre, some plays make demands on the players which the current style of performance cannot fulfil, thereby demanding of the players that they change their performance habits, in what may nevertheless remain a commercially viable enterprise. On the other hand, the

\footnotetext{
${ }^{7}$ This problem is clearly identified by Richard Cave, who points out that "What parts of the play were excised in 1638 it is impossible to gauge, but the known fact of that cutting has a direct bearing on how the play now in the twenty-first century might be viewed as a text for potential performance" (2010:n.p.). Nevertheless, Joshua J. McEvilla has recently found a cast list written on a copy of the 1640 quarto of The Antipodes which includes all the characters of the play, therefore showing that none of the major characters were cut for performance (2012:169). Whatever cuts took place may hence have been distributed throughout the text, instead of focussing on specific characters.
} 
theatre has never had any qualms with cutting and adapting a "recalcitrant" play. As Brecht pointed out in his notes to The Threepenny Opera, "das Theater [...] 'theatert' alles 'ein'" [the theatre turns everything into theatre] (1991:58). This approach, one should add, is perfectly reasonable - a production need not follow the author's wishes - but it can also signal the theatre's tendency to be a conservative medium, relying on acquired techniques rather than being open to external, literary challenges. Regarding this aspect, Stephen Jeffreys' wording becomes highly revealing, when referring to one of the reasons for rewriting the play: "the begging crew are an idealised literary device rather than a collection of dramatic characters" (1992:n.p.; my italics). ${ }^{8}$

Having reached this point, one might do well to dialectically turn the issue on its head. So far, I have suggested that The Antipodes may have been cut in contemporary performance due to possible shortcomings on the part of the theatre practitioners themselves. I would now like to argue that these cuts and changes may reflect a greater misunderstanding and that the theatre practitioners in question may have unwittingly drawn attention to this problem when they decided that parts of the play did not work on the stage. What I mean by this is that, on the academic front, one might benefit from looking again at the notion of a text written for the stage. Brome's play is a text "intended for the [...] stage," written with the stage in mind; but the stage could not, and still cannot, manage the play as it was and is, so that this "for the [...] stage," this intention or intentionality, is partially passed over and parts of the play are cut. The players themselves reject a theatrically intended text. My point is that reading a play as "intended for the [...] stage," in Brome's useful phrasing, is to dwell on an intention with unpredictable effects rather than on a theatrically certifiable situation. And the recognition of this problem may have considerable consequences when one summarily characterises early modern plays, such as Shakespeare's, as scripts written for the stage, as if that intentionality guaranteed the play's adequacy for the stage. Instead of dwelling on this spectacular failure of communication, by insisting on a play's status as only fully understandable in its relation to the stage, one

\footnotetext{
${ }^{8}$ One might perhaps object here to Jeffreys' opposition between literature and drama, where one would rather expect an opposition between literature and theatre or between poetry and drama as literary subcategories.
} 
may, for instance, want to consider the ways in which certain parts of the play appear to display the idiom of the page, rather than that of the stage, without hastening to attribute any demerit to the play because of this, or even to declare it unperformable. This might mean that there would be a literary or, if we prefer, a textual excess in relation to that which, in the play, is more easily amenable to the theatre.

Although Gerald Freeman, the master of the play of the Globe production, does not indicate precisely which parts were cut, he suggests that there may be a problem in the way the onstage audience reacts to the play-within-the-play, in that these characters "are seldom drawn in or interact with the satiric characters being presented" (Freeman 2000:vii). The play-within-the-play mostly lasts from act 2, scene 2, to act 4 . And, indeed, especially in act 2 , scene 2 , and act 3, there often seems to be a parallel arrangement between the onstage audience and the characters of the play-within-the-play. Audience commentary on the entertainment can sometimes take a considerable amount of time, occasionally about half a page. It thereby interrupts the flow of the action and brings the metatheatrical dimension too much to the fore. Alternatively, it can appear as a constant interruption, sometimes, proportionately, of one comment for every two speeches. There is little interaction between the two fictional planes except by way of commentary, so that, when commentary intrudes, the players must be silent and wait for it to be completed, or, as is usually the case, they may need to fill the gap with a pantomimed conversation, in what may become a somewhat artificial situation in the theatre, due to the frequency and length of the interruptions (Parr 2007:43). ${ }^{9}$ Nevertheless, Brome is only possibly taking to an extreme what already were the conventions of the play-within-the-play. ${ }^{10}$ From act 3 onwards and

\footnotetext{
${ }^{9}$ Nevertheless, at least two directors claim to have made this arrangement work. Kim Durban, referring to her Australian production of The Antipodes, points out that "Most alien was the style of asides, requiring the actor to be in what one described as a 'suspended state'" (2010:n.p.). Nevertheless, the production was considered a success. In a discussion of his workshop dedicated to The Antipodes, Brian Woolland also explains that his "concern was how the group of 'comedians' could stay active without upstaging the 'audience' discussions. A delicate balance is required. But (...) once the small groupings and the interactions are established, the scene, which is organisationally very complex on paper, shifts focus with great clarity" (2010:n.p.).

${ }^{10}$ Indeed, with reference only to the printed text, some critics have praised Brome's management of a complex balance between the play-within-the-play and the
} 
especially in act 4, Brome seems to experiment with more effective ways of doing this: he has two characters, Doctor Hughball and Peregrine, increasingly interact with the characters from the playwithin-the-play, and has the onstage audience appear above, on the balcony, so that the action is not so easily disrupted.

But act 2, scene 2 and act 3 do seem to stand out as driven more by literary, or textual, rather than theatrical devices. Their parallel arrangement can remind us, by taking the geometrical metaphor earnestly, of marginalia or glosses, which tend to take their place either underneath or to the side of the main text. Their interaction with the main text is by way of reference, not actual interference. The reader can turn to the gloss and then back to the main text without any special awkwardness. To take another example, in a novel such as Laurence Sterne's Tristram Shandy the narrator often interpolates numerous stories within one another, each story left unfinished, and its characters left hanging in narrative suspension, until the newest tale is told to the end, a strategy that readers may simply accept as clever and amusing. Not so in the theatre, at least not according to the style of performance that has been expected and applied to a play from the Caroline period in a theatre such as the reconstructed Globe.

This unusual type of onstage commentary, which seems to have more in common with written texts than with theatrical performance, may account for the uncomfortable way with which Caroline and contemporary players have dealt with The Antipodes. There may, therefore, be something waiting for the reader that is not always available to the spectator of this play. But in order to access this dimension, one may need to look at The Antipodes as something more than a text intended for the stage, and consider that it may also be a piece of literature that, on occasion, can be read without the stage.

commentary by the onstage audience. Martin Butler has acknowledged Brome's "sophisticated dramatic technique," adding that the play "is difficult and multilayered, yet Brome is wholly in control at every point" (1984:219). Ian Donaldson also finds in Brome "a skill in what might be called lightweight structural engineering" (1970:80) and goes on to identify no fewer than five levels, or rings, of spectators in The Antipodes (90-92). These rings of spectators range from those among the onstage audience who most directly engage with the play-within-the-play to those least engaged in it, not forgetting the final level, comprised of the actual audience at Salisbury Court - and, one might add, the printed play's readers. 


\section{References}

Brecht, Bertolt 1991. Bertolt Brecht Werke. Große kommentierte Berliner und Frankfurter Ausgabe, vol. 25, Schriften 4. Ed. Werner Hetch et al. Berlin/Frankfurt am Main: Aufbau/Suhrkamp.

Brome, Richard 2000 (1640). The Antipodes. Ed. David Scott Kastan \& Richard Proudfoot. London: Nick Hern Books.

Butler, Martin 1984. Theatre and Crisis, 1632-1642. Cambridge: Cambridge University Press.

Cave, Richard 2010. "The Antipodes. Textual Essay." Richard Brome Online. <url: http://www.hrionline.ac.uk/brome/viewOriginal.jsp?play=AN\& type $=$ TEXT $>$. Last accessed 25/10/2013.

Collins, Eleanor Clare 2010. "Richard Brome and the Salisbury Court Contract." Richard Brome Online. <url: http://www.hrionline.ac.uk/brome/viewEssay.jsp?file=EC_SALISBUR Y>. Last accessed 25/10/2013.

Donaldson, Ian 1970. The World Upside-Down: Comedy from Jonson to Fielding. London: Oxford University Press.

Durban, Kim 2010. "Upside down at the bottom of the world: taking Richard Brome to the Antipodes." Richard Brome Online <url: http:/ / www.hrionline.ac.uk/brome/viewEssay.jsp?file=KD_AUSTRAL IA >. Last accessed 25/10/2013.

Erne, Lukas 2003. Shakespeare as Literary Dramatist. Cambridge/New York: Cambridge University Press.

Freeman, Gerald 2000. "A note from the master of the play." The Antipodes. By Richard Brome. Ed. David Scott Kastan and Richard Proudfoot. London: Nick Hern Books: vii-viii.

Greenblatt, Stephen 2008. General Introduction. The Norton Shakespeare. Ed. Stephen Greenblatt et al. 2nd ed. New York: Norton: 1-78.

Gurr, Andrew 1999. "Maximal and Minimal Texts: Shakespeare v. the Globe." Shakespeare Survey 52: Shakespeare and the Globe. Cambridge: Cambridge University Press: 68-87.

- 2008. "The Shakespearean Stage." Ed. Stephen Greenblatt et al. The Norton Shakespeare. 2nd ed. New York: Norton: 79-99.

Homem, Rui Carvalho 2004. "Translating Shakespeare for the Twenty-First Century: Introduction." Ed. Rui Carvalho Homem and Ton Hoenselaars. Translating Shakespeare for the Twenty-First Century. Amsterdam: Rodopi: 1-24.

Jeffreys, Stephen 1992. Introduction. A Jovial Crew, by Richard Brome, adapted by Stephen Jeffreys. By Richard Brome and Stephen Jeffreys. London: Warner Chappell Plays: n. pag. 


$$
\text { (a) ederi 24 (2014) }
$$

Kastan, David Scott 2001. Shakespeare and the Book. Cambridge: Cambridge University Press.

McEvilla, Joshua J. 2012. "The Original Salisbury Court Players of Richard Brome's The Antipodes." Notes and Queries 59/2: 168-171.

Parr, Anthony 2007. Introduction. Three Renaissance Travel Plays (The Travels of the Three English Brothers; The Sea Voyage; The Antipodes). Ed. Anthony Parr. Manchester: Manchester University Press: 1-54.

Sanders, Julie 1999. Caroline Drama - The Plays of Massinger, Ford, Shirley and Brome. Plymouth: Northcote House.

Steggle, Matthew 2004. Richard Brome: Place and Politics on the Caroline Stage. Manchester: Manchester University Press.

Stern, Tiffany 2014. Introduction. A Jovial Crew. By Richard Brome. Ed. Tiffany Stern. London: Bloomsbury: 1-68.

Webster, John 2009 (1623). The Duchess of Malfi. Ed. Leah S. Marcus. London: Methuen Drama.

White, Martin 1998. Renaissance Drama in Action: An Introduction to Aspects of Theatre Practice and Performance. London/New York: Routledge.

Woolland, Brian 2010. "'All I have seen ... are wonders': Directing Brome." Richard Brome Online. <url: http://www.hrionline.ac.uk/brome/ viewEssay.jsp?file=BW_DIRECTING $>$. Last accessed 25/10/2013.

Worthen, W. B. 2005. Print and the Poetics of Modern Drama. Cambridge: Cambridge University Press.

How to cite this note:

Ramalhete Gomes, Miguel. "Intended for the stage: Performance criticism in Richard Brome's The Antipodes." SEDERI 24 (2014): 157-169.

Author's contact: migramalhete@hotmail.com 